\title{
Overview of the use of clean cookstoves in the Brazilian semiarid region
}

\author{
Panorama do uso de fogões melhorados no Semiárido brasileiro
}

Javier Mazorra $^{\mathrm{a}}$
Renata da Costa Barreto $^{\mathrm{b}}$
Paula Ferreira dos Santos $^{\mathrm{c}}$
María Suárez Bonet $^{\mathrm{d}}$
Candela de la Sota $^{\mathrm{e}}$
Guilherme Checco $^{\mathrm{f}}$
Fabio Almeida
Luís Tadeu Assad

${ }^{a}$ Centro de Innovación en Tecnología para el Desarrollo Humano de la Universidad Politécnica de Madrid - itdUPM, Madri, Espanha

E-mail: javier.mazorra@upm.es

${ }^{b}$ Instituto Virtual Internacional de Mudanças Globais - IVIG, Programa de Planejamento Energético, PPE/Coppe/UFRJ, Rio de Janeiro, RJ, Brasil E-mail: rbarreto@ivig.coppe.ufrj.br

'Instituto Virtual Internacional de Mudanças Globais - IVIG, Programa de Planejamento Energético, PPE/Coppe/UFRJ, Rio de Janeiro, RJ, Brasil

E-mail: paula.ferreira@ivig.coppe.ufrj.br

${ }^{d}$ Instituto Brasileiro de Desenvolvimento e Sustentabilidade - IABS, Brasilia, DF, Brasil E-mail: maria.suarez@iabs.org.br

${ }^{e}$ Centro de Innovación en Tecnología para el Desarrollo Humano de la Universidad Politécnica de Madrid - itdUPM, Madri, Espanha E-mail: candelasota@gmail.com

fInstituto Democracia e Sustentabilidade - IDS e Instituto de Energia e Ambiente da Universidade de São Paulo - IEE/USP, São Paulo, Brasil

E-mail: guilherme@idsbrasil.org

${ }^{9}$ Fundação C\&A e Instituto Democracia e Sustentabilidade - IDS, São Paulo, Brasil E-mail: f.almeida@candafoundation.org

${ }^{h}$ Instituto Brasileiro de Desenvolvimento e Sustentabilidade - IABS, Brasília, DF, Brasil E-mail: assadmar@iabs.org.br

doi:10.18472/SustDeb.v10n2.2019.22159

Received: 22/01/2019

Accepted: 12/08/2019

ARTICLE - VARIA

\section{ABSTRACT}

Wood cookstoves are common in the Brazilian semiarid region. Most families use traditional versions, which have a series of social, environmental and health-related impacts. "Improved cookstoves" refer to cleaner and more efficient cookstoves. These include adaptations that improve energy efficiency 
and reduce indoor air pollution, bringing benefits such as the reduction of firewood consumption for cooking, reduction of the emission of polluting gases originating from firewood burning and fewer health impacts, also contributing to forest conservation. Although the improved cookstoves sector is still relatively underdeveloped in the Brazilian semiarid region, in recent years interest in these technological alternatives has increased. In this context, the present study contributes to the compilation and organization of information referring to the use of improved cookstoves in the Brazilian semiarid region.

Keywords: Improved cookstoves; Brazilian semiarid region; Firewood; Energy efficiency.

\section{RESUMO}

O uso de fogão a lenha é comum no Semiárido brasileiro, porém a maioria das famílias usa fogões tradicionais, que trazem um conjunto de impactos sociais, ambientais e relacionados à saúde. Fogões melhorados é o nome dado aos fogões mais limpos e eficientes que os fogões tradicionais de lenha. Eles incluem adaptações que melhoram a eficiência energética e diminuem a poluição do ar no interior dos domicílios, trazendo benefícios como a diminuição na quantidade de lenha necessária para a preparação de alimentos, diminuição de emissões de gases poluentes provenientes da queima da lenha, diminuição dos impactos sobre a saúde e maior preservação da mata. O setor dos fogões melhorados ainda está pouco desenvolvido no Semiárido, mas nos últimos anos vem aumentando o interesse geral por essas alternativas. Neste contexto, o presente estudo contribui para compilar e organizar informações sobre a adoção e a utilização dos fogões melhorados no Semiárido.

Palavras-chave: Fogões melhorados; Semiárido brasileiro; Lenha; Eficiência energética.

\section{INTRODUCTION}

The lack of access to modern energy sources is one of the main limiting factors for the economic and social development of a large part of the world's population (TAKADA et al., 2007). In addition to access to electricity, access to modern forms of energy for cooking that replace traditional uses of biomass, based on simple and low efficiency technologies, is one of the greatest challenges in this area. Almost 2,900 million people (39\% of the world's population) still use biomass for cooking in traditional ways with low efficiency (IEA et al., 2019). This has a series of negative impacts in four areas: climate and environment, health, livelihoods and women and gender (CCA, 2018).

From a climate and environment standpoint, traditional ways of cooking involve a high consumption of solid fuels, especially firewood and charcoal. This, together with incomplete combustion, results in the emission of greenhouse gases (GHG) and other products that contribute to global warming. In addition, about $30 \%$ of the firewood consumed is collected unsustainably, resulting in emissions equivalent to $2 \%$ of global GHG emissions and local deforestation and biodiversity loss (BAILIS et al., 2015; PUTTI et al., 2015).

Due to exposure to smoke, burning fuel also produces negative health effects. This causes about 4 million premature deaths per year, especially affecting women and children, as they spend more time close to cookstoves (WHO, 2018). Women are also the most affected by impacts on livelihoods, since time spent cooking and collecting firewood could be used for other productive activities. When firewood or charcoal are purchased, high fuel consumption can represent a considerable cost for households (PUTTI et al., 2015).

In this context, cooking solutions are combinations of technology and fuel used for cooking that are characterized as cleaner and more efficient than traditional options. Such alternatives include adaptations that improve energy efficiency, reducing the impacts mentioned above. In the Brazilian semiarid region, the most commonly used cooking solution are "improved cookstoves" (ICS), which refer to cleaner and more efficient wood-burning cookstoves when compared to traditional versions (TCS). This article will discuss improved cookstoves. Alternative names include "clean cookstoves" and "efficient cookstoves", and there is a wide diversity of this type of stoves, depending on the fuel used and the way of manufacturing, among other variables. 
Aiming at a broad adoption of cookstoves in the long term, it is essential to take into account the socioeconomic aspects involved in the choice of the way of cooking, but also the various human dimensions, such as cooking habits, including the type of cookstove, fuels, patterns of use and cultural habits, with a specific focus on women's perspective and preferences (RUIZ-MERCADO and MASERA, 2015).

This article is the result of a study that aimed to map and evaluate the use of ICS in the Brazilian semiarid region as a way to reduce the negative impacts linked to the use of TCS, seeking to consolidate the knowledge already available from the region. To this end, a literature review was conducted, complemented with information obtained during fieldwork. Based on this knowledge and using complementary analyses, the study described favourable aspects and restrictions for the development of strategies that promote the dissemination and stimulate the ICS market in the Brazilian semiarid region.

\section{METHODS AND STUDY AREA}

The study was structured considering the approach promoted by the Clean Cooking Alliance (CCA), formerly the Global Alliance for Clean Cookstoves (GACC) (2011). According to this approach, in order to achieve a broad and effective change from TCS to ICS, a market creation strategy should be adopted, considering three lines of action: fostering an enabling environment, strengthening supply and enhancing demand. With this in mind, and based on the series of evaluations promoted by the CCA (ACCENTURE DEVELOPMENT PARTNERSHIPS, 2011a; ACCENTURE DEVELOPMENT PARTNERSHIPS, 2011b; ENERGÍA SIN FRONTERAS et al., 2013), this article begins by analysing the general situation of the semiarid region, considering the use of fuels and the impacts of TCS. Then, the background and political context of ICS in the region, the perspective of families and the availability of ICS are presented. Lastly, the article offers a series of proposals for the sector.

This article is based on a literature review that is complemented with information obtained from fieldwork. The bibliographic research included national surveys and studies, including information on demographics and use of cookstoves and fuels, among others.

The main national databases available were investigated, including the Brazilian Institute of Geography and Statistics (IBGE) and the demographic census, as well as reports on energy and supply/demand of firewood. Reports and studies that analyse previous projects and experiences with cookstoves in the Brazilian semiarid region were also contemplated. In addition, regional and international reports (such as the United Nations Development Programme - UNDP), specialized summaries (such as from CCA or $\mathrm{GIZ}$ ) and scientific papers were consulted. Given the limitations found in obtaining specific information about the semiarid region, information from the broader Northeast region was sometimes used.

Fieldwork included participation in events related to the subject of study and interviews. The events included two courses on agro-ecological cookstoves construction, organized by the Xingó Centre for Coexistence with the Semiarid Region for farmers, stonemasons, technical assistance agents and local associations; the Regional Seminar on Forest Biomass and Energy Efficiency in the Northeast Brazilian region, organized by the Brazilian Institute for Development and Sustainability (IABS); the Seminar for Presentation of Results of the Project "Management of Sustainable Land Use in the Semiarid Northeast of Brazil (Sergipe)", organized by the Plants of the Northeast Association (APNE); the III International Seminar and Course of Coexistence with the Semiarid Region of the Xingó Centre; and a meeting of a community of rural producers interested in ICS.

Six semi-structured interviews were conducted with people who use ICS. Two interviews were conducted with families who had obtained an eco-cookstove as part of a project to promote social technologies carried out within the scope of the Xingó Centre. The other four interviews were conducted with families who participated in a project executed by the NGO Caatinga, which promoted the implementation of ICS in Ouricuri (Pernambuco). The interviews included, among others, questions about the type of technology and fuels used, family habits and difficulties in adopting the technology. An interview was also conducted with Paulo Pedro Carvalho, coordinator of the Caatinga NGO project 
previously mentioned. In this case, the questions were more focused on the general aspects of the project and the lessons learned.

The interviews were conducted according to the ethical procedures established by the IABS. The interviewees were previously informed about the objectives of the study and the confidentiality of the answers. An authorization to record the interviews and take photographs was requested, using an authorization term for the use of images, sound and voice that was read out loud and signed by the interviewees. All interview sessions with cookstove users were accompanied by someone who worked or had worked with the interviewee.

Due to the limited time and difficulties in coordination, it was impossible to carry out more interviews with families, suppliers and executors of ICS projects. While acknowledging the limitations of the collected information, the content was a useful complement to the information available in the literature.

\subsection{STUDY AREA}

The study was focused on the Brazilian semiarid region (Figure 1), located in the Northeast of the country. The states in this region have similar social, economic and environmental characteristics. The semiarid region is characterized by intense periodic droughts and low Human Development Indices (HDI) compared to other parts of the same states and to other regions in Brazil (UNDP et al., 2013). The Caatinga, a unique biome in the world, covers most of the region and is at risk due to deforestation (INPE, 2015).

The São Francisco river crosses the region, being a differentiating element for municipalities that have access to it. In the Northeast region, 9\% of the population depends on unclean fuels and technologies for cooking, corresponding to 5 million people that are exposed to the negative impacts associated with this way of cooking (IBGE, 2016), the highest percentage in Brazil.

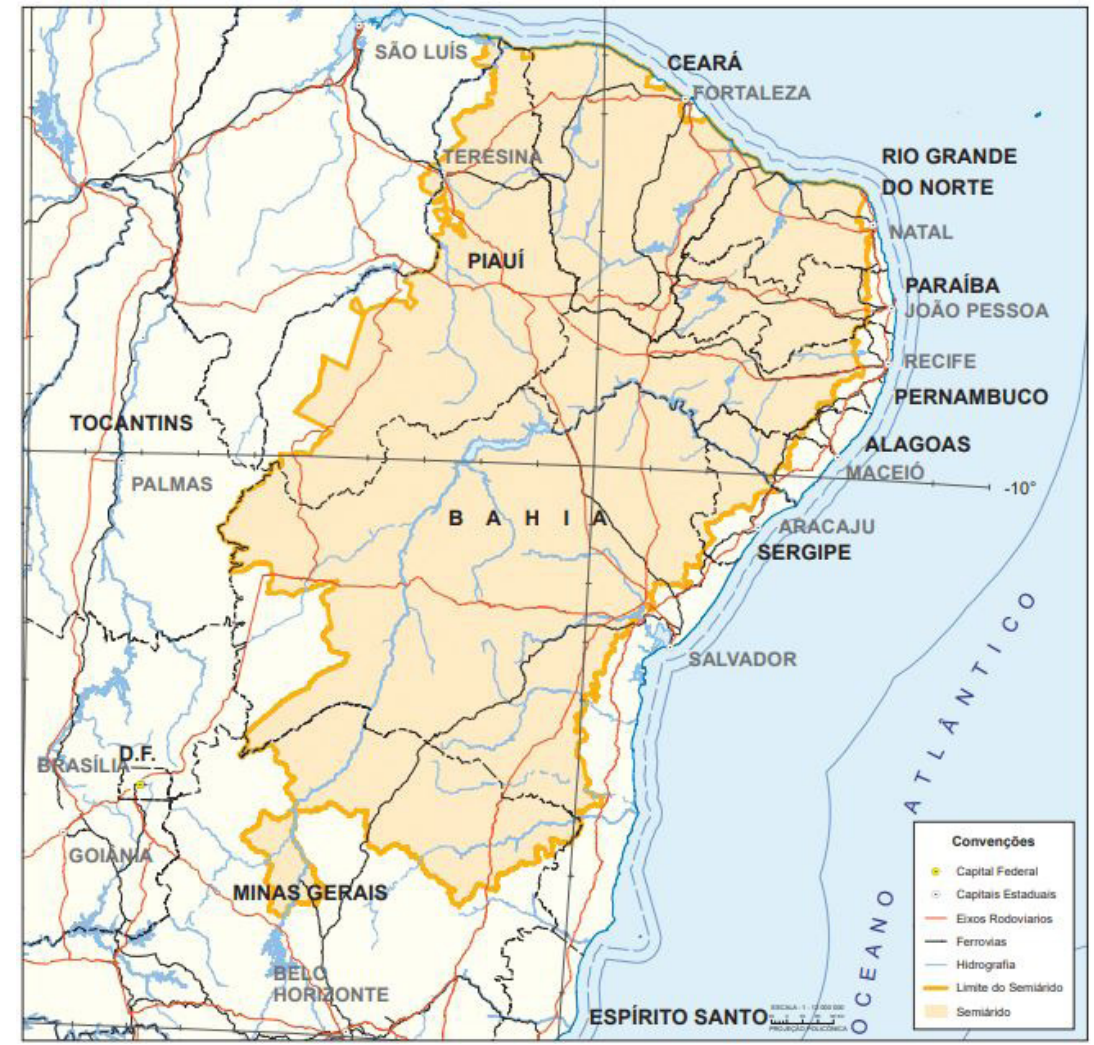

Figure 1 | The Brazilian semiarid region. 


\section{RESULTS}

\subsection{FUELS}

Firewood has traditionally played an important role as an energy source in Brazil, but in recent decades it has been replaced by oil derivates and electricity (EMPRESA DE PESQUISA ENERGÉTICA, 2016). Demand from the household sector, though declining in recent decades (Figure 2), is comparable to that from the industrial sector and is concentrated in rural areas, mainly for cooking. However, as this is a highly dispersed demand, it is very difficult to quantify. According to a survey conducted by the Plants of the Northeast Association (APNE, 2017), rural North-eastern households constitute the largest demand for biomass in the region, representing nearly $30 \%$ of total demand.

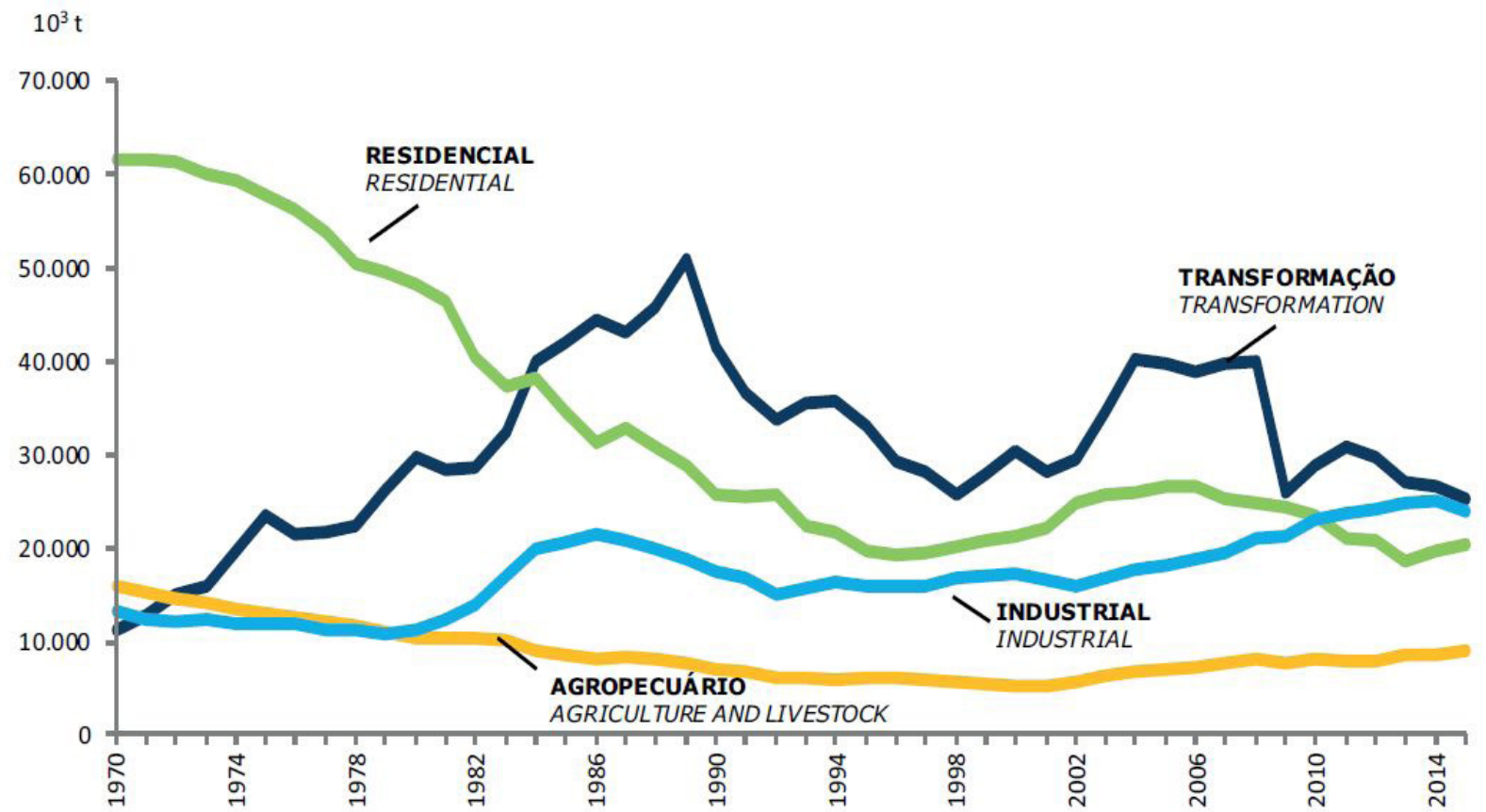

Figure 2 | Wood consumption in the Brazilian market from 1970 to 2014.

Source: EMPRESA DE PESQUISA ENERGÉTICA (2016).

In general, as indicated by Carvalho et al. (2014), Prolenha (2015), and Ramos and Albuquerque (2012), among others, families in the Brazilian semiarid region use mainly liquefied petroleum gas (GLP), charcoal and firewood as fuels. This was confirmed during fieldwork. The choice depends on the type of food to be prepared, the availability and price of each type of fuel, and the economic situation of the family at the time.

The diversification of the cooking options available in households brings greater resilience to families (RUIZ-MERCADO and MASERA, 2015), representing a strategy that improves coexistence with the semiarid region. Thus, the technologies/fuels complement each other, rather than substitute one another (CARVALHO et al., 2014; PROLENHA, 2015). ICS contribute to this resilience strategy by reducing fuel consumption.

Regarding fuel consumption by families, large differences in information and lack of consensus were identified among the sources consulted (UHLIG, 2008; REGUEIRA, 2010; INSTITUTO PERENE, 2013; SGARBI, 2013; CARVALHO et al., 2014; PROLENHA, 2015). This shows the need to deepen research on fuel consumption by families in the semiarid region to better understand the relationship they have with the various fuels and the ways to use them. During the interviews, the difficulty of the families to quantify their consumption of the various fuels used was verified. A synthesis of the information available in the sources consulted (cited above in this paragraph) and the information obtained in the interviews is presented below. 
GLP is present in most households and is widely used, along with the wood cookstoves. In general, GLP is expensive for the families in the region, considering their income. This type of energy is mainly used for foods that require little time to cook, such as heating meals or preparing breakfast, and is valued as quick and comfortable to use (GUALDANI et al., 2015). Firewood is the main fuel for foods that require more time to cook, such as lunch, and it is present in most homes. Lastly, charcoal is also used, but, as identified in the interviews, less frequently than firewood. If charcoal is preferred over firewood, it is mainly due to the lower production of smoke compared to firewood in the TCS (REGUEIRA, 2010; fieldwork).

Although the study region is supplied by electricity, this type of energy is not used for cooking. Whilst ethanol can also be used (in Brazil there exist initiatives to promote ethanol stoves) this does not occur in the studied region. In addition, sugarcane, used to obtain ethanol, is not cultivated in the semiarid region because the crop requires high amounts of water.

Currently, an additional social technology is being disseminated in the Brazilian semiarid region: the biodigester, which obtains biogas from cattle waste (ACCENTURE DEVELOPMENT PARTNERSHIPS, 2011a). Nevertheless, there are still limitations to its dissemination as this technology is more complex and expensive and requires inputs from a considerable amount of cattle.

\subsection{NEGATIVE IMPACTS OF TRADITIONAL STOVES}

With regard to socioeconomic impacts of TCS, the high consumption of fuel leads to a greater amount of time needed for firewood collection. Deforestation and climate change may have an impact on the availability of biomass and, consequently, on the time spent on firewood collection, meaning that people need to walk further to find good quality firewood (MAZORRA, 2017). Some interviews showed this result.

Unlike other parts of the world, Ramos et al. (2008), Ramos and de Alburquerque (2012) and Instituto Perene (2013) identified that in the region of study this task is shared between men and women, sometimes done exclusively by men. This was also identified in the field interviews. The frequency of collection is very heterogeneous, being more frequent during the dry season (RAMOS and DE ALBURQUERQUE, 2012). In general, firewood is obtained in backyards or in woods near households, which may require several kilometres of displacement.

Fieldwork confirmed that women are the main responsible for cooking, assisted by their daughters and often accompanied by the younger children. This makes women and children the main victims of the impacts linked to the use of cookstoves. According to PROLENHA (2015), traditional wood-burning cookstoves are used, on average, for 3.5 hours a day. Additionally, fieldwork showed that a great amount of time is spent cleaning pots, which usually turn black in the TCS.

In conclusion, there are few studies available with information on the collection of firewood, cooking habits and time spent preparing food in the semiarid region, which makes it difficult to fully comprehend the issues arising from the use of cookstoves.

Inefficient burning of solid fuels for cooking causes indoor air pollution from various types of pollutants. Exposure to these pollutants for long periods of time has several health impacts (WHO, 2006; SOTA et al., 2014), such as the emergence of disease (lung cancer, chronic obstructive pulmonary disease, pneumonia and tuberculosis), and cardiovascular, eye and gestational problems (ROYAL COLLEGE OF PHYSICIANS, 2016).

According to CCA (2018), almost 12 million people in Brazil are affected by air pollution inside their own homes, from which more than 21,000 people die every year. Exposure to indoor pollution is one of the main causes of premature death in the world and, in Brazil, is ranked above diseases such as malaria and tuberculosis (FOELL et al., 2011). Yet the level of awareness about the issue in Brazil remains low.

The high consumption of firewood and charcoal from TCS also brings environmental impacts. There is a high uncertainty in data on production and consumption of firewood and charcoal in the Brazilian Northeast region. However, it is known that a considerable part of the consumption has unknown or illegal origin and contributes to the deforestation of native vegetation (NDAGIJIMANA et al., 2015), as well as desertification. 
According to the National Institute for Space Research (INPE, 2015), in 2013/2014 the Caatinga biome covered only $40 \%$ of its original area. As seen during fieldwork, there is a growing concern about ecosystem degradation in the region and efforts are being made to monitor biomass consumed and produced, and to promote firewood from sustainable sources. However, illegal deforestation still occurs, so it is important to adopt measures to prevent deforestation and ensure long-term sustainability of the firewood market. ICS can contribute to these efforts.

Unsustainable extraction of firewood also means that GHG emissions from cookstoves are not offset. In addition, burning firewood or charcoal in TCS leads to the emission of incomplete combustion products, such as methane, carbon monoxide, nitrogen oxides and particulate matter, especially black carbon (BC) (LAMARQUE et al., 2010), which also contribute to climate change. BC, a short-lived pollutant that composes soot, is the second largest contributor to climate change, and $25 \%$ of its emissions come from biomass burning at household level (CCA, 2018). No studies on the contribution of ICS in reducing emissions of BC and other products of incomplete combustion were found in Brazil, which is why its mitigation potential may be undervalued.

\subsection{EVOLUTION OF IMPROVED COOKSTOVES}

The development of ICS in other Latin American countries is much more advanced than in Brazil (ENERGÍA SIN FRONTERAS et al., 2013; CCA, 2018). Countries such as Guatemala and Peru have specific national strategies to address the issue. In spite of the work of organizations such as the Red Latinoamerica y del Caribe de Cocinas Limpias to bring together organizations and universities active in the cookstove sector to facilitate the exchange of knowledge, no Brazilian institution takes part. At the international level, the Clean Cooking Alliance (CCA) leads the efforts in the sector. There are few Brazilian institutions participating in this alliance.

In recent years, the interest in technological alternatives for cooking in Brazil has increased, focusing on rural communities. Table 1 shows a summary of the main ICS programs and projects identified in the Brazilian semiarid region and in the whole country that served as the basis for the present study. The only large-scale initiative found was that of the Institute for Sustainable Development and Renewable Energy (IDER), in Ceará, funded by the state government. Until 2018, the Government of Ceará continued to promote ICS, but casting stoves instead of the masonry stoves promoted by IDER (GOVERNO DO ESTADO DO CEARÁ, 2018). In addition, only one initiative financed with carbon credits was found (Perene Institute in Bahia), and it was not in the semiarid region. Figure 3 shows the evolution of the ICS sector in Brazil.

\section{Improved cookstoves and the commitments made by Brazil}

ICS are aligned with several of the international commitments assumed by Brazil. Neither the National Plan on Climate Change (GOVERNO FEDERAL, 2008) nor the National Plan for Adaptation to Climate Change (MINISTÉRIO DO MEIO AMBIENTE, 2016) have objectives regarding energy for cooking. Nevertheless, ICS can contribute to the climate change mitigation and adaptation objectives that these Plans aim to achieve.

With regard to international agreements, Brazil did not adopt specific targets for limits on indoor air pollution but ratified the Paris Agreement during the 21st Conference of the Parties to the UNFCCC, which aims to reduce GHG emissions in the context of sustainable development. In order to achieve the objective of the Agreement, governments were involved in the construction of their own commitments, based on the so-called Nationally Determined Contributions (NDC).

The Sustainable Development Goals (SDGs) are another global negotiation process in which Brazil participated. These goals defined the global agenda adopted by the United Nations in 2015, consisting of 17 goals and 169 targets to be achieved by 2030 .

The SDGs cover social, environmental, economic and institutional issues related to human needs and to the ability to put the established goals into practice. They also involve actions related to the 
environment, that range from reversing deforestation, protecting forests and biodiversity, and combating desertification, to the adoption of effective measures against climate change, with approaches concerning the use and depletion of natural resources, waste production and energy consumption, among others. ICS can contribute with direct advances on 5 SDGs - 3-Good health and well-being, 5 - Gender equality, 7 - Affordable and clean energy, 11 - Sustainable cities and communities and 13 - Climate action - being an essential part of SDG 7. Additionally, they can support the achievement of another 5 SDGs: 1 - No poverty, 2 - Zero hunger, 4 - Quality education, 8 - Decent work and economic growth and 15 - Live on land.

Table 1 | Compilation of the improved cookstoves projects in Brazil. Source: SGARBI (2013) extended.

\begin{tabular}{|c|c|c|c|c|c|}
\hline Case & Executor & Project & Description & When? & № cookstoves \\
\hline $\begin{array}{c}\text { BIOGAS COOKSTOVES } \\
\text { - PIAUÍ, SEMIARID } \\
\text { REGION }\end{array}$ & $\begin{array}{c}\text { Care } \\
\text { (ACCENTURE } \\
\text { DEVELOPMENT } \\
\text { PARTNERSHIPS, } \\
\text { 2011a) }\end{array}$ & $\begin{array}{c}\text { Producer's energy } \\
\text { Project }\end{array}$ & $\begin{array}{l}\text { Biodigestion of } \\
\text { goat and sheep } \\
\text { waste in regions } \\
\text { where these } \\
\text { animals are the } \\
\text { main source of } \\
\text { waste. }\end{array}$ & 2010 & 6 biodigesters \\
\hline \multirow[b]{2}{*}{$\begin{array}{c}\text { EFICIENT COOKSTOVES } \\
\text { - BAHIA }\end{array}$} & \multirow[b]{2}{*}{$\begin{array}{l}\text { Perene Institute } \\
\text { (AMBIENTAL PV, } \\
\text { 2014) }\end{array}$} & \multirow[b]{2}{*}{$\begin{array}{l}\text { Sustainable } \\
\text { Recôncavo } \\
\text { Program }\end{array}$} & \multirow{2}{*}{$\begin{array}{l}\text { Replacement of } \\
\text { rudimentary and } \\
\text { inefficient stoves } \\
\text { with improved } \\
\text { wood-burning } \\
\text { stoves financed } \\
\text { with carbon } \\
\text { credits. }\end{array}$} & $\begin{array}{c}2011- \\
2014\end{array}$ & 1.000 cookstoves \\
\hline & & & & $\begin{array}{l}2015- \\
2017\end{array}$ & $\begin{array}{l}4.800 \text { cookstoves } \\
\text { (forecast) }\end{array}$ \\
\hline $\begin{array}{l}\text { AGROECOLOGICAL } \\
\text { COOKSTOVES - } \\
\text { PERNAMBUCO AND } \\
\text { PIAUÍ, SEMIARID } \\
\text { REGION }\end{array}$ & $\begin{array}{c}\text { NGO Caatinga } \\
\text { (CAATINGA, } \\
\text { 2016) }\end{array}$ & $\begin{array}{c}\text { Cookstoves } \\
\text { from Araripe: } \\
\text { Energy Efficiency } \\
\text { in Family } \\
\text { Households }\end{array}$ & $\begin{array}{l}\text { Construction of } \\
\text { agroecological } \\
\text { stoves through } \\
\text { participatory } \\
\text { methodology } \\
\text { and training } \\
\text { of instructors. } \\
\text { Project financed } \\
\text { by MMA and } \\
\text { CAIXA. }\end{array}$ & 2012 & 550 cookstoves \\
\hline $\begin{array}{l}\text { GEOAGROECOLOGICAL } \\
\text { COOKSTOVES - XINGÓ } \\
\text { MESOREGION, } \\
\text { SEMIARID REGION }\end{array}$ & $\begin{array}{l}\text { NGO Agendha } \\
\text { (AGENDHA, } \\
\text { 2016) }\end{array}$ & $\begin{array}{c}\text { Geoagroecological } \\
\text { cookstoves }=- \\
\text { Firewood }-\mathrm{CO} 2+ \\
\mathrm{O}+\mathrm{H} 2 \mathrm{O}+\text { Life }\end{array}$ & $\begin{array}{l}\text { Construction of } \\
\text { geoagroecological } \\
\text { stoves in rural } \\
\text { communities. } \\
\text { Project financed } \\
\text { by MMA and } \\
\text { CAIXA. }\end{array}$ & $\begin{array}{c}2012- \\
2015\end{array}$ & $\begin{array}{c}\text { More than } 600 \\
\text { cookstoves }\end{array}$ \\
\hline $\begin{array}{l}\text { PROMOTING ECO- } \\
\text { EFFICIENT STOVES IN } \\
\text { AREAS SUSCEPTIBLE } \\
\text { TO DESERTIFICATION } \\
\text { - PIAUÍ, CEARÁ AND } \\
\text { PERNAMBUCO, } \\
\text { SEMIARID REGION }\end{array}$ & $\begin{array}{c}\text { Prolenha } \\
\text { (PROLENHA, } \\
\text { 2015) }\end{array}$ & $\begin{array}{l}\text { Study for the } \\
\text { formulation of a } \\
\text { strategy for the } \\
\text { promotion of } \\
\text { efficient stoves } \\
\text { in the semiarid } \\
\text { region. }\end{array}$ & $\begin{array}{c}\text { Research } \\
\text { developed to } \\
\text { evaluate the } \\
\text { performance } \\
\text { and perception } \\
\text { of communities } \\
\text { about the impacts } \\
\text { of various } \\
\text { technologies } \\
\text { of improved } \\
\text { cookstoves. }\end{array}$ & $\begin{array}{l}2014- \\
2015\end{array}$ & - \\
\hline
\end{tabular}




\begin{tabular}{|c|c|c|c|c|c|}
\hline \multirow[b]{2}{*}{$\begin{array}{c}\text { ECOLOGICAL } \\
\text { COOKSTOVES - CEARÁ, } \\
\text { SEMIARID REGION AND } \\
\text { OTHER REGIONS }\end{array}$} & \multirow{2}{*}{$\begin{array}{l}\text { IDER and } \\
\text { Governo do } \\
\text { Ceará } \\
\text { (SGARBI, 2013; } \\
\text { GOVERNO DO } \\
\text { ESTADO DO } \\
\text { CEARÁ, 2017) }\end{array}$} & \multirow[b]{2}{*}{$\begin{array}{l}\text { Eco-Efficient } \\
\text { Cookstoves / } \\
\text { Sustainable } \\
\text { Cookstoves } \\
\text { Program }\end{array}$} & \multirow{2}{*}{$\begin{array}{l}\text { Installation of } \\
\text { improved stoves } \\
\text { supported by the } \\
\text { State Government, } \\
\text { reaching a large } \\
\text { number of people. } \\
\text { They started out } \\
\text { as masonry stoves, } \\
\text { but in the end } \\
\text { casting stoves were } \\
\text { installed. }\end{array}$} & $\begin{array}{l}2005- \\
2011\end{array}$ & $\begin{array}{c}26.000 \\
\text { cookstoves }\end{array}$ \\
\hline & & & & $\begin{array}{c}2015- \\
2017\end{array}$ & 4.500 cookstoves \\
\hline $\begin{array}{l}\text { ECO-COOKSTOVES IN } \\
\text { THE SERTÃO OF PAJEÚ, } \\
\text { SEMIARID REGION }\end{array}$ & $\begin{array}{l}\text { Projeto Dom } \\
\text { Helder Camara } \\
\text { (REGUEIRA, } \\
\text { 2010) }\end{array}$ & $\begin{array}{l}\text { Use of ecological } \\
\text { stoves by rural } \\
\text { families in the } \\
\text { semiarid region }\end{array}$ & $\begin{array}{c}\text { Installation of eco- } \\
\text { stoves in the sertão } \\
\text { of Pajeú for rural } \\
\text { families }\end{array}$ & $\begin{array}{l}2012- \\
2013\end{array}$ & 865 cookstoves \\
\hline
\end{tabular}

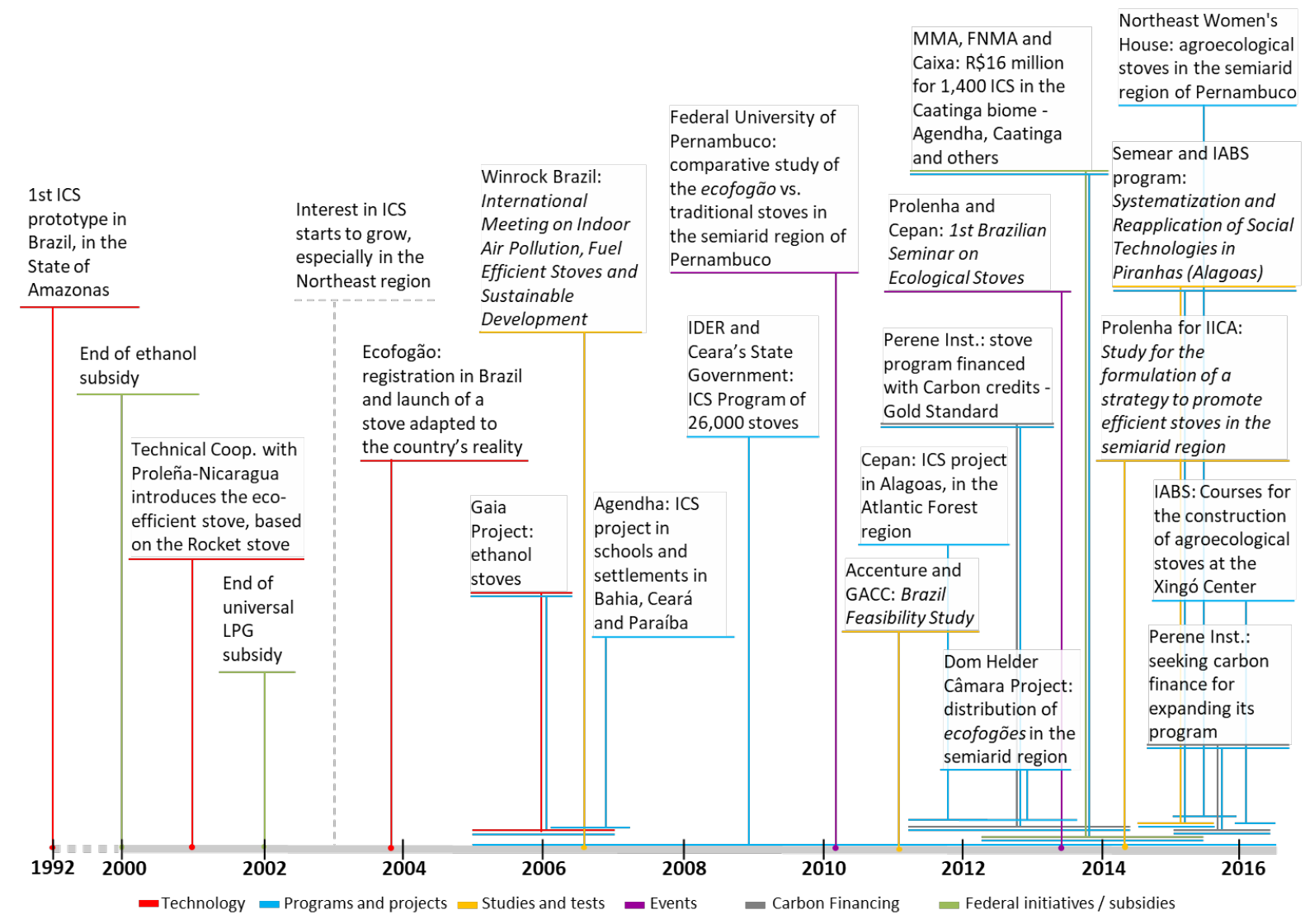

Figure 3 | Evolution of the improved cookstoves sector in Brazil.

Source: Authors 


\subsection{FAMILY PERSPECTIVES ON THE USE OF STOVES}

\section{Habits and preferences}

Wood cookstoves are an important part of the culinary tradition of the semiarid region, but in everyday life families also value other options which cook faster, such as the GLP stove. Traditional meals in this region include corn, cassava, milk, green beans and various meats, such as sun-dried meat. Meals are, generally, highly nutritious and tasty. Fieldwork showed that it is common to mix several types of food in one meal. Consequently, cookstoves with several burners are preferred in order to allow the cooking of different foods at the same time. When it comes to cooking, wood-burning stoves are the most traditional in the semiarid region. It was also found that different types of pots are used: traditional metal pots, clay pots and pressure cookers.

The most valued characteristics of wood cookstoves are: having two to three burners, with space for larger pots; the possibility of adapting the stove aesthetically to the preferences of the family; the presence of an oven, though not essential; the presence of a barbecue grill, as it allows for cooking meat; and durability, which is more important than the portability of the stove (RAMOS and ALBUQUERQUE, 2012; PROLENHA, 2015; and interviews).

\section{Women's role}

Women play a central role in cookstove interventions. They are in charge of cooking and, in some cases, of collecting firewood. The temporary migration of men to other regions in search of work (ALBUQUERQUE, 2014) is another determining factor that renders women responsible for the general wellbeing of the family. Consequently, they are the ones who suffer the most from the impacts of TCS and are the most aware of the benefits that ICS bring. Although they have less power in decisionmaking, when compared with men (SANTOS, 2014), their participation in ICS interventions is essential in order to increase the options for long-term success (CCA, 2018). Moreover, in an environment marked by the underestimation of the activities developed by women, ICS can contribute with women's empowerment (MAZORRA, 2017).

As noted during fieldwork, there are active social movements in the region formed by women who are beginning to promote the use of ICS. These associations can play a key role in disseminating these alternatives.

\section{Vision of improved cookstoves}

ICS is gaining increasing recognition in the semiarid region among rural families. Community associations and NGOs have been working to disseminate the available technologies, usually in the form of social technologies, which aim to promote resilience. According to fieldwork and other studies (LEITE, 2010; PROLENHA, 2015), the general perception of families who have received an ICS is positive, mainly because of the reduction in smoke indoors (which reduces eye problems and respiratory diseases, makes the kitchen and pans cleaner, and reduces the smell of smoke) and the reduction in the consumption of firewood, which saves time and effort in collection. In addition, in the experience developed by Gualdani et al. (2015), the ICS available and the biodigester were the technologies that aroused most interest among families.

Thus, ICS are alternatives that generate interest in the semiarid region. However, cases of misuse of ICS were identified during fieldwork, leading to smaller positive impacts than predicted in the literature. This shows the importance of developing training programs on the use and maintenance of cookstoves and their installation, as well as monitoring their use.

\subsection{AVAILABLE IMPROVED COOKSTOVES}

According to cookstove-related publications, websites of organisations that promote the use of this equipment, manufacturers and field visits, there are various types of ICS, depending on the materials and the way they are manufactured. The combustion chamber and chimney are the most important 
parts. A series of stonemasonry ICS developed or promoted by NGOs that have been active in the sector were identified. The approximate cost is $\mathrm{R} \$ 500$, including labour. A description of these ICS, considering the promoting institution, is shown below, in line with Table 1:

- Institute for Sustainable Development and Renewable Energy (IDER) promoted the Ecoeficient cookstove, that is based on the concept of social technologies and is built with a structural base of bricks complemented by a chimney (LEITE, 2010).

- Perene Institute developed the Efficient cookstove, built with bricks, but with a manufactured combustion chamber. When the present research was performed, it was the only Brazilian cookstove certified by the Gold Standard. It is also certified by the Aprovecho Research Centre (AMBIENTAL PV, 2014).

- NGO Agendha developed and has been promoting the Geoagroecological cookstove, a social technology built exclusively with stones, sand, clay and water. The slab is made of refractory clay, a material that is sometimes difficult to find and complex to work with (CAATINGA, 2014). This material makes the slab take longer to warm up but keeps the heat much longer than the iron slabs. The cookstove includes a small oven.

- NGO Caatinga developed the Agroecological cookstove, a social technology based on the Geoagroecological stove of the NGO Agendha, which changed the material of the slab to iron and the chimney to steel, with the objective of reducing the time needed to heat the slab and increase the durability of the chimney. This type of cookstove continued to be disseminated by the rural communities themselves and by other entities, such as the Xingó Centre for Coexistence with the Semiarid. This shows the interest generated by the initiative, but also raises concerns about the risk that the new cookstoves may not comply with basic quality aspects due to the lack of the stonemasons training.

In addition to stonemasonry ICS, industrial stoves were identified, from which the most relevant are listed below:

- Campestre Cookstove: developed by the company Ecofogão (2019), linked to Prolenha, an NGO that has been working for many years in the area of ICS in several Latin American countries. It is a high-quality stove, with prices ranging from $R \$ 467$ (two burners) to $R \$ 550$ (three burners). These prices do not include shipping (the factory is located in Minas Gerais) or installation. According to tests conducted by the Federal University of Pernambuco, this cookstove reduces by more than $50 \%$ the consumption of firewood compared to TCS (REGUEIRA, 2010). The distance to the Northeastern municipalities considerably increases the final price of the stove, but the company has shown interest in installing a factory in that region.

- Prefabricated cookstoves: manufactured with reinforced concrete, expanded clay and refractory ceramic. They are high quality stoves sold by big retailers, but their price is too high for many families in the semiarid region (more than $\mathrm{R} \$ 1,000$ ).

- Casting stoves: there are several stoves of this type with various options, all of them manufactured in Southern Brazil, though sold throughout the country. The price of the most basic model is $\mathrm{R} \$ 645$ (freight not included).

Other technologies identified were biodigesters, ethanol cookstoves, electric cookstoves and the GLP cookstove. With the exception of the last one, none of these technologies are common in rural households in the semiarid region. The biodigester provokes interest in the communities but, as previously indicated, its high cost and complexity limit its use.

Among all of the alternatives available, only one type of casting cookstove and ethanol cookstove are registered in CCA's catalogue of cooking solutions. Furthermore, only one of the ethanol stoves has passed tests certified by the CCA that prove the stove's performance. 


\section{DISCUSSION AND PROPOSALS FOR THE SECTOR}

As indicated above, in order to achieve broad and effective change from traditional stoves to ICS, a strategy should be adopted around three lines of action: foster an enabling environment, strengthen supply and enhance demand (GACC, 2011). Bearing this in mind, the following elements limit the development of the sector in the semiarid region:

- Institutional framework: there are no standards or regulation of ICS in the country, there is little coordination among the actors, there is limited awareness of the impacts of TCS and ICS are not a priority for public institutions, with the exception of the Government of Ceará.

- Information and knowledge: in general, available knowledge about the sector is limited, dispersed and unstructured. There is little information about available ICS, testing of different models and studies on stoves in general are scarce, and there is no information about the adoption of already distributed ICS. In addition, the participation of the scientific community is low, which is limiting knowledge generation and systematization.

- Users: ICS are beginning to be known and to generate interest in the region, but the ability to buy one is still reduced. In addition, families that already have an ICS often misuse it, compromising its positive impacts.

- ICS initiatives: there are few market-based initiatives. Additionally, experience in financing through the carbon market is limited. Also, monitoring of households after ICS installations is scarce.

- Technology: the distance to cookstove manufacturing centres limits interventions with manufactured stoves and sometimes makes it difficult to access spare parts in the semiarid region. Furthermore, the lack of training of stonemasons who build masonry cookstoves can negatively impact the quality of installed ICS.

After an analysis of intervention options to promote the ICS sector in the semiarid region based on specialized publications (ACCENTURE DEVELOPMENT PARTNERSHIPS, 2011b; CÓRDOVA and CASTRO, 2012; ENERGIA SIN FRONTERAS et al., 2013), a set of priority intervention areas was identified. In the first place, the creation of an institutional framework that facilitates the coordination and articulation of actors should be encouraged, and it is important to raise awareness among society in general and policy makers. Deforestation, a problem that is already among the general concerns of Brazilian society, can be used as a vector to raise awareness about the impacts of traditional cookstoves.

The involvement of the academic community is also an important factor, especially regarding the development of tests, studies and research. In addition, it will play an important role in the design of monitoring and evaluation systems for stove interventions, and in the definition of a standard, with subsequent certification mechanisms. Linked to this standard, training processes for manufacturers and stonemasons should be developed.

When promoting ICS, it is recommended to define differentiated strategies according to the level of poverty and the characteristics of the region. For the non-poor population, it is understood that the development of the market is the most appropriate strategy. For families living in extreme poverty, it is recommended to integrate ICS projects with other interventions, such as public health policies. Lastly, it is important to strengthen the cookstoves market, especially with regard to the availability of spare parts and maintenance and repair services. Without this, it will be hard to ensure the adoption of improved cookstoves in the long term.

In addition to the factors listed above, "technology packages" based on simple technology transfer, without considering social and environmental aspects, should be avoided. In this sense, it is always important to involve families and communities, to work from a gender perspective and to focus on the adoption of the cookstoves. Ultimately, innovation and networking will facilitate the development of the sector. 


\section{CONCLUSIONS}

The fact that Brazil is a country of continental proportions, with great differences between its regions, makes the problem of traditional cookstoves in the semiarid region go unnoticed in the country's statistics. In general, the difficulties obtaining information about the semiarid region means having to resort to data from the Northeast, which limits the understanding of the challenges of the studied region.

The present research found that the improved cookstoves sector is poorly developed in the Brazilian semiarid region. However, initiatives that show an increase in interest in such alternatives are beginning to take place. Although this is a positive aspect, there is still concern as to whether these initiatives will achieve the expected results in the long term. On the one hand, the fact that most of the initiatives promote stonemasonry stoves means that the efficiency of the final product may be compromised by the quality of the materials and the capacity of the stonemasons. On the other hand, when there is a lack of monitoring, families often make inappropriate use of the stoves, limiting their positive effects. However, the interest identified among the user families is a very important aspect that can be positively explored.

Other countries in Latin America, Africa and Asia have extensive experience in the improved cookstove sector. Brazil should take advantage of this experience and take into account the lessons learned, becoming more involved in international discussions about the subject.

\section{ACKNOWLEDGEMENTS}

This work is part of the study "State of the Improved Cookstoves Sector in the Brazilian Semiarid", carried out jointly by the Brazilian Institute of Development and Sustainability (IABS), the Innovation and Technology for Development Centre of the Polytechnic University of Madrid (itdUPM), the Institute for Democracy and Sustainability (IDS) and the International Virtual Institute for Global Change (IVIG) of the Alberto Luiz Coimbra Institute for Graduate Studies and Engineering Research, Federal University of Rio de Janeiro (COPPE/UFRJ). The study was financed by the Inter-American Institute for Cooperation on Agriculture (IICA) through the Technical Cooperation Project BRA/IICA/14/001, in the areas susceptible to desertification.

\section{REFERENCES}

ACCENTURE DEVELOPMENT PARTNERSHIPS. Brazil Feasibility Study - Sector Mapping. [S. I.]: Global Alliance for Clean Cookstoves, 2011a.

ACCENTURE DEVELOPMENT PARTNERSHIPS. Brazil Feasibility Study-Intervention Options. [S. I.]: Global Alliance for Clean Cookstoves, 2011b.

AGENDHA. Fogões Geoagroecológicos. [S. I.]: Agendha 2016. Disponível em: <http://agendha.org.br/2016/07/05/ fogoes-geoagroecologicos/>. Acesso em: abr. 2018.

AGUIAR, J. M. Vínculos entre acceso a energía, cambio climático y género en países en desarrollo: una aproximación a través de las cocinas mejoradas. 2017. Tese (Doutorado em Engenharia Química) - Universidad Politécnica de Madrid, Madrid, 2017.

ALBUQUERQUE, C. F. de. Migração Camponesa: dominação e resistência ao capital. Revista de Políticas Públicas, São Luís, Número especial, p. 453-458, jul. 2014.

AMBIENTAL PV. Efficient Cookstoves in Bahia II: project design document. [S. I.]: The Gold Standard, 2014.

ASSOCIAÇÃO DE PLANTAS DO NORDESTE. Estudo de atualização da estimativa de demanda e oferta de biomassas no Nordeste brasileiro e cenários futuros. In: SEMINÁRIO DE APRESENTAÇÃO DE RESULTADOS DO MANEJO DO USO SUSTENTÁVEL DA TERRA NO SEMIÁRIDO DO NORDESTE BRASILEIRO (SERGIPE), 2017, Recife. Apresentação... Recife: 2017. 
BAILIS, R. et al. The carbon footprint of traditional woodfuels. Nature Climate Change, [S. I.], v. 5, n. 3, p. 266-272, jan. 2015.

BRASIL. Ministério do Meio Ambiente. Plano Nacional de Adaptação à Mudança do Clima. Brasília, DF: 2016.

CAATINGA. Sertão que dá Certo: fogão geoagroecológico. Ouricuri: Caatinga, 2014.

CAATINGA. Fogões do Araripe: eficiência energética na propriedade familiar. [S. I.]: Caatinga, 2016.

CARVALHO, R. L. T. et al. Impacts of two improved wood-burning stoves on the indoor air quality: practices in Peru and Brazil. In: INDOOR AIR CONFERENCE. Proceedings... Honkong: Aalborg Universitet, 2014.

CLEAN COOKING ALLIANCE. Site corporativo. [S. I.]: CCA, 2018. Disponível em: <https://www.cleancookingalliance. org>. Acesso em: 30 jul. 2019.

CÓRDOVA, U.; CASTRO, A. Facilitando la adopción de las cocinas mejoradas: guía para planificadores o implementadores de proyectos de cocinas mejoradas. Lima: EnDev/GIZ, 2012.

ECOFOGÃO. Ecofogão: fogões a lenha ecológicos. Site corporativo. [S. I.]: Ecofogão, 2019. Disponível em: <http:// ecofogao.com/>. Acesso em: 30 jul. 2019.

EMPRESA DE PESQUISA ENERGÉTICA. Balanço Energético Nacional - Ano-Base 2015. Rio de Janeiro: Empresa de Pesquisa Energética, 2016.

ENERGÍA SIN FRONTERAS; FUNDACIÓN SOLAR; UNIVERSIDAD POLITÉCNICA DE MADRID. Análisis del Mercado de Estufas y Combustibles de Guatemala: opciones de intervención. [S. I.]: Global Alliance for Clean Cookstoves, 2013.

FOELL, W. et al. Household cooking fuels and technologies in developing economies. Energy Policy, [S. I.], v. 39, p. 7487-7496, 2011.

GACC. Igniting change: a strategy for universal adoption of clean cookstoves and fuels. Washington, DC: GACC, 2011.

GOVERNO DO ESTADO DO CEARÁ. Portal do Governo. [S. I.]: Governo do Estado do Ceará, 2018. Disponível em: <https://www.ceara.gov.br/>. Acesso em: 30 jul. 2019.

GOVERNO FEDERAL. Plano Nacional Sobre Mudança do Clima: versão para consulta pública. Brasília, DF: Comitê Interministerial sobre Mudança do Clima, 2008.

GUALDANI, C.; FERNÁNDEZ, L.; GUILLÉN, M. L. Convivência com o Semiárido brasileiro: reaplicando saberes através de tecnologias sociais. Brasília, DF: Editora IABS, 2015.

IEA; IRENA; UNSD; WB; WHO. Tracking SDG 7: the energy progress report 2019. Washington, DC: The World Bank, 2019.

INSTITUTO BRASILEIRO DE GEOGRAFIA E ESTATístICA. Censo Brasileiro 2010. Rio de Janeiro: IBGE, 2012. Disponível em: <www.censo2010.ibge.gov.br>. Acesso em: 20 mar. 2018.

INSTITUTO BRASILEIRO DE GEOGRAFIA E ESTATÍSTICA. Pesquisa Nacional por Amostra de Domicílios 2015. Rio de Janeiro: IBGE, 2016.

INSTITUTO BRASILEIRO DE GEOGRAFIA E ESTATÍSTICA. Semiárido Brasileiro (23 Nov. 2017). Rio de Janeiro: IBGE, 2017. 1 mapa, color

INSTITUTO NACIONAL DE PESQUISAS ESPACIAIS. Inpe Nordeste mapeia desmatamento da Caatinga. São Paulo: Ministério da Ciência, Tecnologia, Inovações e Comunicações, 2015. Disponível em: <http://www.inpe.br/ noticias/noticia.php?Cod_Noticia=3895>. Acesso em: 29 jul. 2019.

INSTITUTO PERENE. Efficient Cookstoves in the Bahian Recôncavo region: monitoring report. [S. I.]: Instituto Perene, 2013. 
LAMARQUE et al. Historical (1850-2000) gridded anthropogenic and biomass burning emissions of reactive gases and aerosols. Atmospheric Chemistry and Physics, [S. I.], v. 10, n. 15, p. 7017-7039, 2010.

LEITE, L. H. V. Comunicação, Accountability e Promoção de Políticas Públicas: o caso do projeto de Fogões Eficientes no uso da mídia. 2010. Trabalho Final (Curso de Especialização em Democracia Participativa, República e Movimentos Sociais) - Universidade Federal de Minas Gerais, Brasília, DF, 2010.

NDAGIJIMANA, C.; PAREYN, F. G. C.; RIEGELHAULPR, E. Uso do solo e desmatamento da Caatinga: um estudo de caso na Paraíba e no Ceará - Brasil. Estatística Florestal da Caatinga, Recife, v. 2, p. 18-29, ago. 2015.

ORGANIZAÇÃO DAS NAÇÕES UNIDAS. ODS 7 - Energía asequible y no contaminante: por qué es importante. [S. I.]: ONU, 2016.

PNUD; FUNDAÇÃO JOÃO PINHEIRO; IPEA. Atlas do Desenvolvimento Humano no Brasil. [S. I.: s. n.], 2013. Disponível em: <http://atlasbrasil.org.br/2013/pt/>. Acesso em: 20 dez. 2018.

PROLENHA. Estudo para a formulação de estratégia do fomento aos fogões eficientes no Semiárido. [S. I.]: Prolenha, 2015.

PUTTI, V. R. et al. The State of the Global Clean and Improved Cooking Sector. Technical Report 007/15. Washington, DC: Esmap e Global Alliance for Clean Cookstoves, 2015.

RAMOS, M. A.; ALBUQUERQUE, U. P. The domestic use of firewood in rural communities of the Caatinga: how seasonality interferes with patterns of firewood collection. Biomass and Bioenergy, [S. I.], v. 39, p. 147-158, 2012.

RAMOS, M. A. et al. Use and knowledge of fuelwood in an area of Caatinga vegetation in NE Brazil. Biomass and Bioenergy, v. 32, p. 510-517, 2008.

REGUEIRA, T. M. Comparação entre a eficiência de dois modelos de fogão a lenha e seus impactos sobre o desmatamento da Caatinga. 2010. Trabalho de Conclusão de Curso (Bacharelado em Ciência Biológicas) Universidade Federal de Pernambuco, Recife, 2010.

ROYAL COLLEGE OF PHYSICIANS. Every breath we take: the lifelong impact of air pollution. Report of a working party. London: RCP, 2016.

RUIZ-MERCADO, I.; MASERA, O. Patterns of Stove Use in the Context of Fuel -Device Stacking: rationale and implications. EcoHealth, [S. I.], v. 12, n. 1, p. 42-56, 2015.

SANTOS, J. M. O papel da mulher na produção. In: CONTI, I. L.; SCHROEDER, E. O.; MEDAGLIA, V. R. (Org.). Construindo saberes, cisternas e cidadania: formação para a convivência com o Semiárido brasileiro. Brasília, DF: Editora IABS, 2014, p. 126-127.

SGARBI, F. de A. Modelos de transição energética residencial e o acesso a serviços energéticos limpos: uma análise a partir de dois estudos de caso. 2013. Dissertação (Mestrado - Programa de Pós-Graduação em Energia) - Universidade de São Paulo, São Paulo, 2013.

SOTA, C. de la. et al. Effectiveness of Improved Cookstoves to Reduce Indoor Air Pollution in Developing Countries. The Case of the Cassamance Natural Subregion, Western Africa. Journal of Geoscience and Environment Protection, [S. I.], v. 2, n. 1, p. 1-5, 2014.

TAKADA, M.; RIJAL, K.; MORRIS, E. Energizing the least developed countries to achieve the Millennium Development Goals: the challenges and opportunities of globalization. In: UNITED NATIONS MINISTERIAL CONFERENCE OF THE LEAST DEVELOPED COUNTRIES, 2007, Istanbul. Making Globalization Work for LDCs. Istambul: Pnud, 2007.

UHLIG, A. Lenha e carvão vegetal no Brasil: balanço oferta-demanda e métodos para a estimação do consumo. 2008. Tese (Doutorado em Energia) - Universidade de São Paulo, São Paulo, 2008.

WHO. Fuel for life: household energy and health. [S. I.]: WHO, 2006.

WHO. Household air pollution and health: key facts. [S. I.]: WHO, 2018. Disponível em: <https://www.who.int/ news-room/fact-sheets/detail/household-air-pollution-and-health>. Acesso em: 29 jul. 2019. 